\title{
Herd demography, sexual segregation and the effects of forest management on Bornean banteng Bos javanicus lowi in Sabah, Malaysian Borneo
}

\author{
Katie L. Journeaux ${ }^{1,2, *}$, Penny C. Gardner ${ }^{1,2}$, Hong Ye Lim,3, \\ Jocelyn Goon Ee Wern' ${ }^{2}$, Benoît Goossens ${ }^{1,2,4,5, *}$ \\ ${ }^{1}$ Organisms and Environment Division, Cardiff School of Biosciences, Cardiff University, Biomedical Sciences Building, \\ Museum Avenue, Cardiff CF10 3AX, UK \\ ${ }^{2}$ Danau Girang Field Centre, c/o Sabah Wildlife Department, Wisma Muis, 88100 Kota Kinabalu, Sabah, Malaysia \\ ${ }^{3}$ Universiti Malaysia Sabah, Jalan UMS, 88400 Kota Kinabalu, Sabah, Malaysia \\ ${ }^{4}$ Sabah Wildlife Department, Wisma Muis, 88100 Kota Kinabalu, Sabah, Malaysia \\ ${ }^{5}$ Sustainable Places Research Institute, Cardiff University, 33 Park Place, Cardiff CF10 3BA, UK
}

\begin{abstract}
Between 1973 and 2010, 39.5\% of Sabah's (Malaysian Borneo) natural forest cover was lost to deforestation and conversion to agriculture, therefore the remaining population of endangered Bornean banteng Bos javanicus lowi is being driven towards extinction. The Bornean banteng's herd demography, sexual segregation and the effects of forest management were investigated at 393 camera locations in 6 forest reserves using generalised estimating equations (GEE) fitted via a generalised linear model (GLM). A total of 43344 camera trap nights and 832 independent banteng events were captured at 93 locations. The identification of 183 bantengs included 22 herds ( $>1$ individual) and 12 solitary bulls, with a herd size range of 2 to 21 . Significantly larger herds were observed in forest with $<8$ yr of post-logging regeneration (PLR), whereas herds were smaller in forest with $<3,4$ and $16 \mathrm{yr}$ of PLR. Within these forests, herds were significantly larger along logging roads than in open sites and on forest trails. Herds were significantly larger in upland compared to lowland dipterocarp forest, but significantly smaller when closer to the forest border. Bachelor herds were observed as frequently as mixed-sex herds, and there was a significantly higher capture frequency of female herds in the dry season, supporting the theory of sexual segregation. Frequency of calf births was highest in March and September, and calf captures peaked in June and July. This study contributes to a better understanding of banteng ecology, and will assist in the production of effective management strategies aimed at providing suitable habitat for re-population and enabling banteng population persistence.
\end{abstract}

KEY WORDS: Endangered species · Bos javanicus lowi · Forest management · Demography · Sexual segregation · Camera trapping

\section{INTRODUCTION}

Tropical forests are the richest terrestrial ecosystem on Earth (Gentry 1992) and contain many of the world's 'biodiversity hotspots' (Myers et al. 2000), yet are experiencing the greatest forest loss of all forest do-

${ }^{*}$ Corresponding author: katie.1.journeaux@btinternet.com

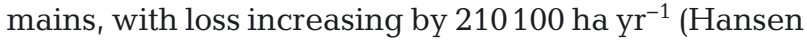
et al. 2013). Between 1990 and 2010, tropical forest cover was reduced from 1635 million ha to 1514 million ha, with 32.9 million ha lost in Southeast Asia (Achard et al. 2014). Overexploitation and agricultural activities are the primary threats to species worldwide

(C) The authors 2018. Open Access under Creative Commons by Attribution Licence. Use, distribution and reproduction are unrestricted. Authors and original publication must be credited. 
(Maxwell et al. 2016). Crop, livestock and tree plantations are the major direct causes of tropical deforestation. Logging, mining and petroleum development also contribute directly to tropical deforestation; however, they also indirectly promote deforestation by increasing the accessibility to otherwise remote areas and facilitating poaching (Butler \& Laurance 2008). Sparsely populated areas are being cleared rapidly; for example, the Amazon for large-scale cattle ranching and industrial soy farming, and Southeast Asia, including Borneo, Sumatra, and New Guinea, for oil palm and rubber plantations (Sodhi \& Ehrlich 2010). Of the 3 major tropical regions, Southeast Asian forests are experiencing the highest rates of forest loss (Sodhi et al. 2004), therefore requiring urgent conservation attention.

Forest cover in Borneo is being lost at approximately twice the rate of other tropical forests in the world (Gaveau et al. 2014). Between 1973 and 2010, $39.5 \%$ of forest in Sabah, Malaysian Borneo, was lost to selective logging, fire and conversion to oil palm and timber plantations (Gaveau et al. 2014). Of this forest loss, $97 \%$ occurred in habitat suitable for the Bornean banteng Bos javanicus lowi (Gaveau et al. 2014, Gardner et al. 2016), likely the rarest mammal in Sabah now that the Sumatran rhinoceros Dicerorhinus sumatrensis has been declared extinct in the wild in Malaysia (Havmøller et al. 2016).

Banteng Bos javanicus is a sexually dimorphic wild cattle species and is categorised as 'Endangered' by the IUCN Red List of Threatened Species (Gardner et al. 2016). The most recent global population estimate was 8000 individuals (Gardner et al. 2016). Three subspecies are recognised: Java banteng B. j. javanicus found in Java and Bali, Burma banteng B. $j$. birmanicus existing on the Asian mainland, and Bornean banteng B. j. lowi present in Borneo (Hassanin \& Ropiquet 2007), in Sabah, Kalimantan and possibly Sarawak (Gardner et al. 2014). The first survey of the Bornean banteng carried out in Sabah in the early 1980s estimated the population at 300 to 550 individuals (Davies \& Payne 1982); however, this probably declined to $<300$ in the late 1990s (Boonratana 1997). Precise present-day Bornean banteng population and subpopulation sizes are unknown, although there is possibly 1 subpopulation of $>50$ individuals (the agreed minimum viable population size) present in Sabah (Gardner et al. 2016). The reduction and fragmentation of habitat and its conversion to agriculture, poaching and increased risk of disease transmission from domesticated cattle are severely threatening the Bornean banteng, with many of the remaining subpopulations confined to protected areas (Gardner et al. 2016).

Banteng form cohesive social groupings (Srikosamatara 1993), which are important aspects of their social behaviour and environment. Herd sizes of large herbivores are primarily functions of foraging strategy and anti-predator behaviour (Kie 1999), and explain, for example, increases in herd sizes in open habitat with reduced canopy cover (Gerard \& Loisel 1995, Kie 1999). Additionally, herd size and dynamics, including herd formation and division, can determine the habitat selection of large herbivores, as observed for bison Bison bison (Fortin et al. 2009). This is supported by larger herds of banteng being observed in open forest (Gray 2012) and grasslands (Pudyatmoko \& Djuwantoko 2006) in comparison to smaller herds observed in dense forest with continuous canopy cover, in Cambodia and Java, respectively. Herd sizes may vary in response to frequent human disturbance causing weak bonds in herds, thus instigating less permanent herd sizes (Pudyatmoko \& Djuwantoko 2006). Herd sizes may also differ between seasons (Pudyatmoko \& Djuwantoko 2006), as banteng herds often aggregate around water holes in the dry season when rainfall is limited (Nguyen 2009).

Herd sex (i.e. gender composition) provides information on ecological factors including the expression of sexual segregation, which is commonly exhibited by sexually dimorphic ungulates outside the mating season (Ruckstuhl 2007). Banteng bachelor herds of mixed ages, and banteng cow and calf groups are known to occur frequently, with mixed temporary assemblages occurring during the mating season or in large open areas (Gardner et al. 2016). Sexual segregation is more likely to occur during the birth period because the behavioural differences between males and females become more pronounced (Bon \& Campan 1996, Ruckstuhl 2007); females become more asocial, timid (Copland 1974) and more dependent on water and rich food sources as a result of the additional demands of gestation and lactation (Bon \& Campan 1996). No rut or calving season has been observed for B. j. lowi (Gardner et al. 2014), although exploring the expression of sexual segregation may allow rut or calving seasons to be observed. Research into understanding the sexual segregation of ungulates has been conducted; the causes are still poorly understood (Ruckstuhl 2007), but could include ecological, physiological, social or foraging factors (Main et al. 1996).

Species with wider ecological niches, particularly herbivores, are more tolerant towards logging and 
may even benefit from post-logging conditions (Meijaard \& Sheil 2008). B. j. javanicus occupy secondary forest formations resulting from logging and fires; however, this has not been observed in $B . j$. birmanicus (Gardner et al. 2016). B. j. lowi thrive on the temporary abundance of pioneer species present in the early stages of post-logging regeneration when not hunted, but evidence of bark stripping by $B . j$. lowi suggests a lack of grassland forage, hunting pressure or heavy disturbance (Gardner 2015). Timber harvesting that creates open spaces may be beneficial in providing sufficient space for larger banteng herds; however, energy-demanding behaviour is reduced in open areas during hot hours (Gardner 2015). Increased anthropogenic disturbance may cause herds to separate and also increase stress levels, which is likely to impact banteng breeding activity and behaviour (Gardner et al. 2014). Furthermore, $B$. $j$. lowi have reduced body conditions in conventionally logged forests compared to reduced-impact logging (RIL) forests (Prosser et al. 2016).

Collaborations between scientists, managers and conservationists to produce science-based wildlife management strategies is increasing and has been identified as a requirement for the effective management and conservation of ungulates (Apollonio et al. 2017). Understanding the mechanisms that influence the demography of increasingly small and isolated ungulate populations is a conservation priority, and is essential to prevent future extinctions (Tatin et al. 2009). Bornean banteng are important ecosystem engineers, but are severely threatened and are being driven towards extinction (Gardner et al. 2016).

The aims of this study were to investigate the herd demography of the Bornean banteng, specifically the herd size, sex and composition, and to explore the expression of sexual segregation in regenerating forest in Sabah. Understanding banteng herd demography will provide baseline data on their behaviour and ecology - including their vigilance (Roberts 1996), predation risk and population density - and on habitat structure (Marino \& Baldi 2014). This enhanced scientific understanding of their demography will enable the desired management and conservation of the Bornean banteng and the complex system they inhabit. Informative baseline data will indicate changes in the population and environment, thus will facilitate future management. Since timber harvesting creates open spaces and facilitates increased growth of pioneer species that provide temporary resources, we hypothesised that banteng herds would be larger in forests with less than 8 yr post-logging regeneration, and that herds would be larger in open sites than on forest trails and logging roads. We also hypothesised that banteng express sexual segregation and that more banteng calves would be born in the dry season than in the wet season.

\section{MATERIALS AND METHODS}

\section{Study sites}

Six forest reserves in Sabah (Malaysian Borneo) were surveyed using remote infrared camera traps: Tabin Wildlife Reserve (TWR), Malua Forest Reserve (MFR), Maliau Basin Conservation Area Buffer Zones (MBCABZ), Sipitang Forest Reserve (SPTFR), Sapulut Forest Reserve (SPLFR) and Kuamut Forest Reserve (KMTFR) (Fig. 1).

TWR ( $5^{\circ} 14^{\prime} \mathrm{N}, 118^{\circ} 42^{\prime} \mathrm{E}$, east Sabah) has been a totally protected area $\left(1106 \mathrm{~km}^{2}\right)$ since 1989 , comprising small areas of virgin jungle surrounded by secondary forest, which consists of lowland $(<500 \mathrm{~m})$, upland (500 to $1000 \mathrm{~m}$ ) and seasonal freshwater swamp dipterocarp forest together with mangrove forest and nipah palm forest in riparian areas (Sabah Forestry Department 2005). TWR was last logged conventionally in 1989 (Sabah Forestry Department 2005), 22 yr prior to this study.

MFR ( $5^{\circ} 7^{\prime} \mathrm{N}, 117^{\circ} 39^{\prime} \mathrm{E}$, central Sabah) became a Class 1 Protection forest reserve $\left(340 \mathrm{~km}^{2}\right)$ in 2011 (Reynolds et al. 2011). It comprises lowland, upland and seasonal freshwater swamp dipterocarp forest. This reserve was last logged using conventional and RIL techniques in 2007 (New Forests Ltd 2008), 4 yr prior to the present study.

MBCABZ ( $4^{\circ} 47^{\prime} \mathrm{N}, 116^{\circ} 53^{\prime} \mathrm{E}$, south central Sabah) became a Class 1 Protection forest reserve in 1997 (Sabah Forestry Department 2005). It consists of lowland, upland and seasonal freshwater swamp dipterocarp forest, as well as scrub (0 to $4 \mathrm{~m}$ ) (Sabah Forestry Department 2005) and riparian fringes. The buffer zones $\left(357 \mathrm{~km}^{2}\right)$ used in this study were last logged using RIL in 1997 (Sabah Forestry Department, staff, pers. comm.), 16 yr prior to the present study.

SPTFR $\left(4^{\circ} 45^{\prime} \mathrm{N}, 115^{\circ} 43^{\prime} \mathrm{E}\right.$, west Sabah) is a commercial forest $\left(2589 \mathrm{~km}^{2}\right)$ that contains lowland and upland dipterocarp forest, lower montane forest (1000 to 2500 m) (Sabah Forestry Department 2005), riparian forests and scrub. This area is logged and severely degraded. SPTFR comprises unlogged and clear-felled areas that are converted to tree plantation. Clear-felling of commercial timbers in Sipitang is conducted at $7 \mathrm{yr}$ intervals. The area that was used in this study was most recently logged between 2010 


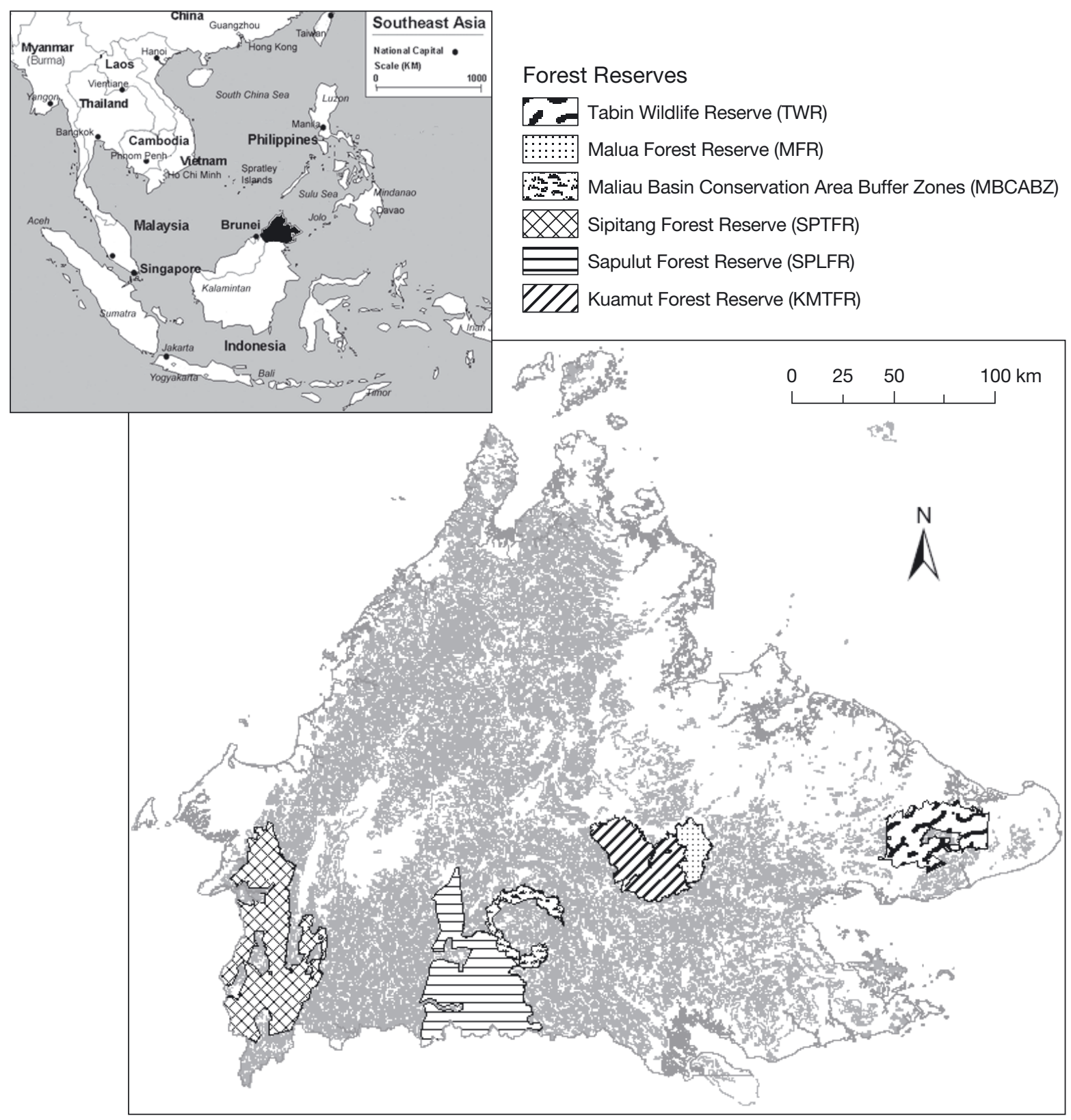

Fig. 1. Sabah, Malaysian Borneo (inset), and location of the 6 study sites: Kuamut Forest Reserve and Malua Forest Reserve in central Sabah, Maliau Basin Conservation Area Buffer Zones and Sapulut Forest Reserve in south central, Sipitang in the west and Tabin Wildlife Reserve in the east

and 2014 (Sabah Forest Industries 2011), 3 yr or less prior to our surveys.

SPLFR $\left(4^{\circ} 22^{\prime} \mathrm{N}, 116^{\circ} 34^{\prime} \mathrm{E}\right.$, south central Sabah) is a commercial forest $\left(2419 \mathrm{~km}^{2}\right)$ consisting of lowland and upland dipterocarp forest, as well as montane forest. Conventionally logged until 2003, it is currently being logged using RIL techniques or managed as a plantation for timber. Logging last occurred in this forest compartment between 2005 and 2014 (Sabah Forestry Department staff, pers. obs.).
KMTFR $\left(5^{\circ} 4^{\prime} \mathrm{N}, 117^{\circ} 26^{\prime} \mathrm{E}\right.$, central Sabah), is a commercial forest $\left(1152 \mathrm{~km}^{2}\right)$ that contains lowland dipterocarp forest. The logging coupe permit was issued in 2006 for conventional logging in the forest compartments used in this study (R. Ong pers. comm.). Therefore, logging occurred 8 yr or less prior to this study.

The number of years since logging activity in each forest reserve, prior to this study, determined the age of post-logging regeneration (PLR) for each forest 
reserve. PLR, therefore, represents the duration that forest reserves have had to regenerate with no logging activity.

\section{Camera trapping}

Behavioural data on the Bornean banteng was collected using non-invasive, remote, passive infrared camera traps: Reconyx HC500, Reconyx PC800 and Reconyx PC850 (Reconyx). Camera trap data originated from 2 different studies using (1) a grid layout and cameras positioned on an ad hoc basis where banteng signs (tracks and dung) were located in TWR and MFR (Gardner 2015) and (2) a state-wide survey for banteng across Sabah in which camera traps were deployed where signs of banteng were located (P. C. Gardner \& B. Goossens unpubl. data). Table 1 shows the camera trapping method used in each forest reserve location. A camera trap station consisted of 2 Reconyx Professional Hyperfire cameras fixed to opposing trees, approximately 1 to $1.5 \mathrm{~m}$ above the ground to maximise the chances of capturing bantengs and identifying individuals. A minimum distance of $0.5 \mathrm{~km}$ was maintained between camera trap stations to maximise the chance of photographing banteng in the area. Camera traps detected heat and movement, triggering 3 consecutive photographic captures at $1 \mathrm{~s}$ intervals, with no time delay between activations. All camera trap photographs were digitally stamped with the event date, time and temperature. Camera traps operated for a minimum survey period of $90 \mathrm{~d}$, and were checked every $28 \mathrm{~d}$ to ensure functionality. Camera trapping effort, which refers to the survey duration (sum of all $24 \mathrm{~h}$ operational camera trap nights), was calculated from the date the camera trap was set to the date it was retrieved for all forests. If the camera was no longer functioning, the date of the last event was used. The habitat vegetation (lowland dipterocarp, upland dipterocarp, seasonal freshwater swamp, scrub, lower montane forest or industrial tree plantation) and elevation were recorded at each camera trap station. Percentage leaf cover was extracted from photographs of the canopy, taken directly above each station using a Samsung WP10 waterproof allweather $12.2 \mathrm{MP} \times 5.0$ digital zoom compact camera on minimum optical zoom. Percentage leaf cover was estimated from monochrome photographs using the software Leaf Cover Calculator v.1.0 (G. Macdonald $\&$ H. Macdonald). Each camera trap location was categorised as forest trail, open site or logging road, and the presence of salt licks was recorded. The distance

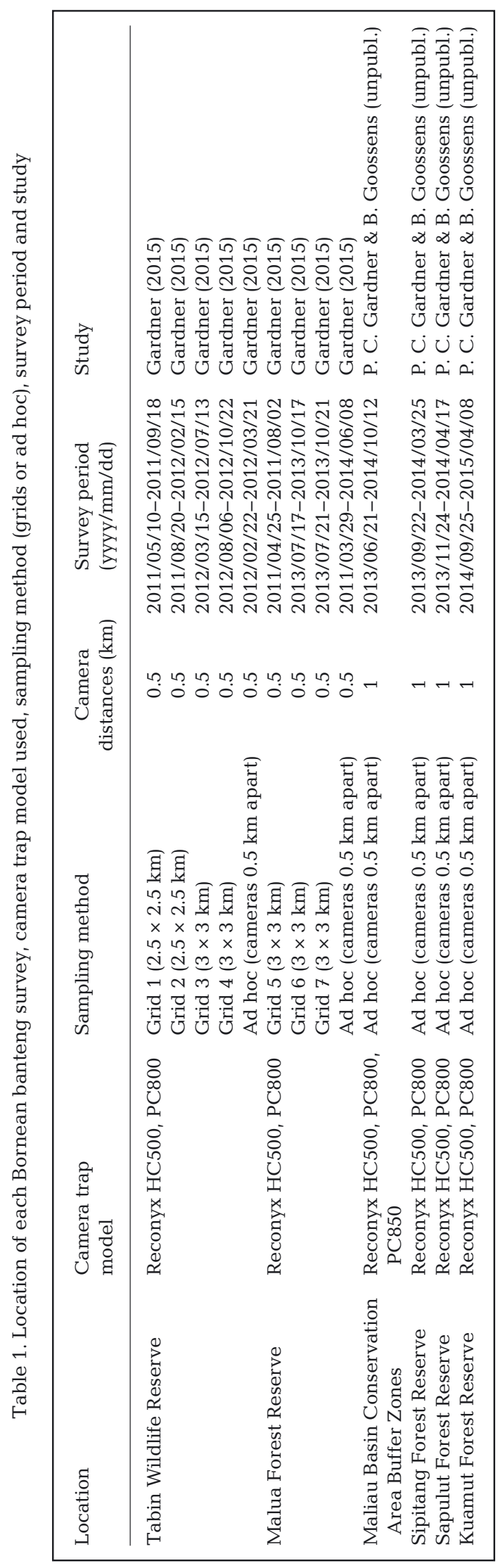


(in $\mathrm{m}$ ) between each camera trap station, nearest village and forest border was extracted post hoc using ArcGIS v.10.1 (ESRI) (H. Y. Lim et al. unpubl. data). Incidences of poaching, which included armed and unarmed people, shotgun cartridges, snares, carcasses, lone dogs, gaharu/sandalwood harvesters and poachers' camps, or camera trap stations that were stolen (2 camera traps station ${ }^{-1}$ ) was recorded (P. C. Gardner et al. unpubl. data).

\section{Herd demography}

Bantengs captured on camera trap within each forest reserve were defined as subpopulations, including forests that were adjacent (MFR and KMTFR); therefore, 6 subpopulations and their respective herd sizes were studied. Individuals were identified using a series of natural marks, including scars on the body, ear tears, horn shape and size, and natural coat colourations (P. C. Gardner \& B. Goossens unpubl. data). Recognition and recaptures of solitary individuals and herds ( $>1$ individual) by morphology and scars were recorded in each forest reserve. Herd size was estimated from the number of bantengs photographed. Male and female morphological characteristics were used to calculate adult sex percentages for each event (Gardner et al. 2014). Bantengs were categorised into 3 broad age classes based on clear differences in body size: adult (male or female), juvenile (up to $50 \%$ smaller than adult cow) and calf (more than $50 \%$ smaller than adult cow). This classification has been applied to a banteng population in Baluran $\mathrm{Na}$ tional Park, Indonesia, using direct observations (Pudyatmoko \& Djuwantoko 2006). Calf births were estimated from the first date of appearance on camera and from their approximate body size. Herd composition was categorised as: (1) male herd, (2) female herd, (3) mixed-sex herd, (4) mixed-sex herd including calf (calves), (5) female(s) and calf (calves), (6) solitary male, (7) solitary female and (8) unknown, due to low light levels or photographs obscured by vegetation. Juveniles could not be reliably sexed so were disregarded when categorising the herd composition. All captures were classified according to 1 of 2 seasons: (1) the wet season, which was defined as between October and March, and (2) the dry season, between April and September, for all forest reserves, due to the reduced impacts of drought and El Niño-Southern Oscillation events (Walsh 1996). Daily rainfall data (mm) collected in Danum Valley, east Sabah, provided by the South East Asia Rainforest Research Partnership (SEARRP), was applied to all forest reserves.

\section{Data preparation}

The data set comprised discrete explanatory variables (number of bulls, cows, juveniles and calves, herd size and poaching and stolen camera trap station incidences), categorical explanatory variables (study design, herd composition, years of PLR, camera trap site, salt lick presence, season and habitat vegetation) and continuous explanatory variables (percentage encounter rates of herd compositions, temperature, rainfall, elevation, canopy cover and the distances of each camera trap station to the nearest village and forest border).

Yasuda (2004) studied medium- to large-sized mammals using camera traps and defined successive photographs as independent when separated by at least $30 \mathrm{~min}$, and Phan \& Gray (2010) suggested 20 minutes for Bos javanicus birmanicus. Preliminary observations showed that an intermission length of 90 min between camera trap captures accommodated a range of herd behaviours: travelling, foraging and resting. Therefore, longitudinal independence was defined by discounting any banteng individual or herd captured within 90 min of the previous event, unless the individual or herd was identified as different. It was assumed that the banteng's choice to join others was not constrained by availability of other banteng.

\section{Statistical analysis}

All statistical analyses were conducted using the statistical software package R v.2.15.2 (R Development Core Team 2012). As a result of the clustered, longitudinal and repeated measures data and the individual observations not being statistically independent, generalised estimating equations (GEE) were fitted using a generalised linear model (GLM) following the protocol of Vaughan et al. (2007), using the error distribution 'Poisson' and library 'geepack'. This allowed the analysis of hierarchical and correlated data, and accounted for spatial autocorrelation (Højsgaard et al. 2006). GEEGLM models were used to test for differences in herd sizes between study design (grid or ad hoc), forest reserve regeneration age, season, camera trap site, salt lick presence, herd sex, temperature, rainfall, habitat vegetation, elevation, canopy cover, distance to the nearest village and forest border, and poaching and stolen camera trap station incidences (Table 2). Backwards stepwise deletion was used to produce the final, most robust GEEGLM model 
Table 2. The questions investigated (response term explanatory term), and their respective statistical test and model number. Explanatory terms: study design (grid or ad hoc), forest regeneration age (years of post-logging regeneration), season, site (camera trap location), salt lick (presence), sex (herd sex), temperature, rainfall, habitat vegetation, elevation, canopy cover, distance_village (distance to the nearest village), distance_forest (distance to the nearest forest border), poaching, stolen camera stations and month. GEEGLM: generalised estimating equations fitted using a generalised linear model; OR: odds ratio;

GAM: generalised additive model

\begin{tabular}{|c|c|c|c|}
\hline \multicolumn{2}{|l|}{ Question } & \multirow{2}{*}{$\begin{array}{l}\text { Statistical test } \\
\text { GEEGLM, transformed into OR }\end{array}$} & \multirow{2}{*}{$\frac{\text { Model no. }}{1}$} \\
\hline Herd size & $\begin{array}{l}\sim \text { Study design }+ \text { regeneration age }+ \text { season }+ \text { site }+ \\
\text { salt lick }+ \text { sex }+ \text { temperature }+ \text { rainfall }+ \text { habitat vegetation } \\
+ \text { elevation }+ \text { canopy cover }+ \text { distance_village }+ \\
\text { distance_forest }+ \text { poaching }+ \text { stolen camera stations }\end{array}$ & & \\
\hline \multicolumn{2}{|c|}{ Capture frequencies sex } & ANOVA and Tukey tests & 2 \\
\hline \multicolumn{2}{|c|}{ Herd sex $\sim$ season } & ANOVA and Tukey tests & $3,4,5$ \\
\hline \multicolumn{2}{|c|}{ Number of calves $\sim$ season } & Poisson GLM & 6 \\
\hline \multicolumn{2}{|c|}{ Number of calves $\sim$ month } & Poisson GAM & 7 \\
\hline
\end{tabular}

including significant (and 1 marginally non-significant) explanatory terms. Pearson residuals were used to validate model output. GEEGLM results were transformed into odds ratios (OR), a measure of association between an environment and an outcome (Szumilas 2010), by taking the exponential. OR compared the relative odds of an outcome of interest occurring in a particular environment as: $\mathrm{OR}=1$ : environment does not affect odds of outcome; OR $>1$ : environment related with higher odds of outcome; and OR < 1: environment related with lower odds of outcome (Szumilas 2010).

One-way analysis of variance (ANOVA) and Tukey post hoc tests were used to investigate the expression of sexual segregation by testing for differences in capture frequencies and the effect of season upon each herd sex in all forest reserves collectively. A Poisson GLM was used to test for significant differences in the number of calves born between the seasons due to the approximately equal variance to the mean and the acceptable degree of over-dispersion.
A Poisson generalised additive model (GAM) with a log link function was fitted to analyse the association between the number of calves captured by camera traps and the month of the year. Month was fitted with a cyclic cubic smoothing spline to allow for cyclical non-linear trends (Table 2).

\section{RESULTS}

\section{Survey effort}

During the study period (April 2011 to April 2015), a total of 832 independent events of banteng were captured from 93 camera traps over 43344 camera trap nights in 6 forest reserves (Table 3). Over 2400 camera trap nights were discounted because of electronic failure or camera trap theft. A total of 30 banteng events were discounted because they were captured within $90 \mathrm{~min}$ of the previous event and violated our assumption of independence.

Table 3. Total number of camera trap (CT) stations, number of CT stations that captured banteng, total number of CT nights (operational for $24 \mathrm{~h}$ ), number of independent events (banteng individual or herd not captured within 90 min of the previous event, unless the individual or herd was identified as different), herds ( $>1$ individual), solitary bulls and identified banteng for each forest reserve

\begin{tabular}{|c|c|c|c|c|c|c|c|c|c|c|c|}
\hline \multirow[t]{2}{*}{ Forest Reserve } & \multirow{2}{*}{$\begin{array}{l}\text { Total no. } \\
\text { of CT } \\
\text { stations }\end{array}$} & \multirow{2}{*}{$\begin{array}{c}\text { No. CT } \\
\text { stations that } \\
\text { captured } \\
\text { banteng }\end{array}$} & \multirow{2}{*}{$\begin{array}{l}\text { Total no. } \\
\text { of CT } \\
\text { nights }\end{array}$} & \multirow{2}{*}{$\begin{array}{l}\text { No. of } \\
\text { indepen- } \\
\text { dent } \\
\text { events }\end{array}$} & \multirow{2}{*}{$\begin{array}{l}\text { No. } \\
\text { of } \\
\text { herds }\end{array}$} & \multirow{2}{*}{$\begin{array}{l}\text { No. of } \\
\text { solitary } \\
\text { bulls }\end{array}$} & \multirow[b]{2}{*}{ Total } & \multicolumn{3}{|c|}{ No. of identified banteng } & \multirow{2}{*}{ Calves } \\
\hline & & & & & & & & Bulls & Cows & Juveniles & \\
\hline Tabin Wildlife Reserve & 129 & 23 & 13942 & 38 & 3 & 2 & 27 & 12 & 10 & 2 & 3 \\
\hline Malua Forest Reserve & 148 & 26 & 14859 & 273 & 4 & 1 & 40 & 16 & 13 & 4 & 7 \\
\hline $\begin{array}{l}\text { Maliau Basin Conservation } \\
\text { Area Buffer Zones }\end{array}$ & 26 & 14 & 5162 & 160 & 6 & 2 & 35 & 13 & 15 & 2 & 5 \\
\hline Sipitang Forest Reserve & 30 & 11 & 3620 & 65 & 5 & 6 & 29 & 10 & 13 & 4 & 2 \\
\hline Sapulut Forest Reserve & 30 & 7 & 2480 & 37 & 1 & 1 & 14 & 6 & 5 & 0 & 3 \\
\hline Kuamut Forest Reserve & 30 & 12 & 3281 & 259 & 3 & 0 & 38 & 21 & 9 & 3 & 5 \\
\hline
\end{tabular}




\section{Herd demography}

A total of 183 bantengs were identified, including 22 herds and 12 solitary bulls, with more bulls identified than cows (Table 3 ). The size of banteng encounters (the sighting of banteng herds or solitary individuals) in each photographic capture varied with forest reserve, and ranged from solitary individuals to herd sizes of up to 21. KMTFR had the largest encounter range of 1 to 21 individuals, whereas SPTFR had the smallest encounter range of 1 to 8 (Fig. 2). The herd composition most often encountered was solitary bulls in TWR (51.4\%), SPTFR (37.1\%) and SPLFR ( $47.2 \%)$, mixed-sex herds in MFR (48.1\%) and KMTFR $(30.5 \%)$, and mixed-sex herds and solitary bulls in

Tabin Wildlife Reserve
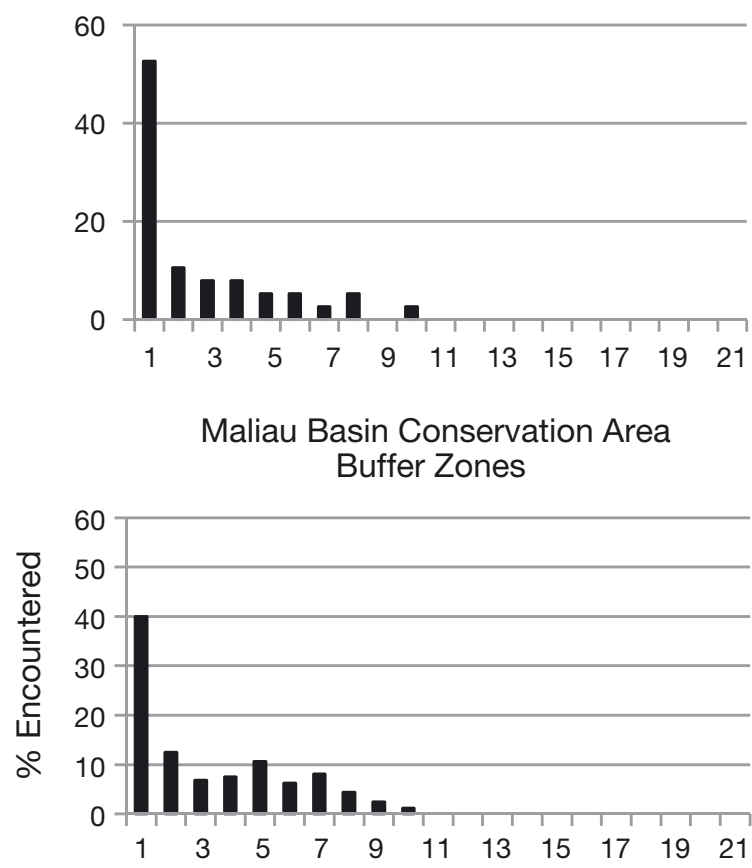

Sapulut Forest Reserve

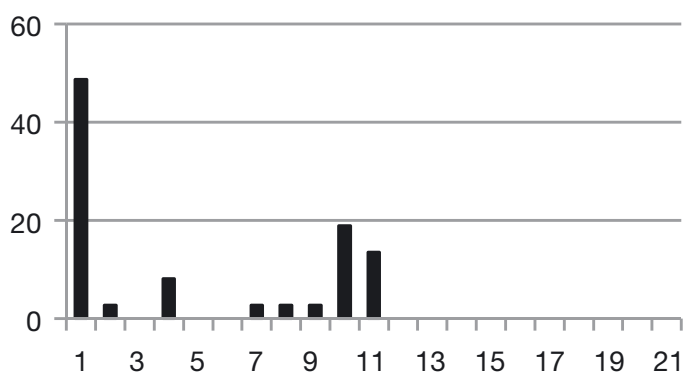

MBCABZ (34.0\%) (Table 4). In TWR, MBCABZ, SPLFR and KMTFR, banteng encounters mainly comprised bulls, SPTFR mainly cows, and MFR had an almost even mean adult percentage. Intra-herd comparisons revealed TWR had the highest number of bulls $(69 \%)$ within herds and SPTFR the highest number of cows $(52 \%)$ within herds. In all forest reserves collectively, banteng encounters comprised more bulls ( $58 \pm 1.3 \%$ ) than cows $(42 \pm 1.3 \%$ ) (Fig. 3 ).

\section{Banteng herd sizes}

We found that forest regeneration age (ANOVA: $\left.\chi^{2}=34.2, \mathrm{p}<0.001\right)$, type of site within the forest
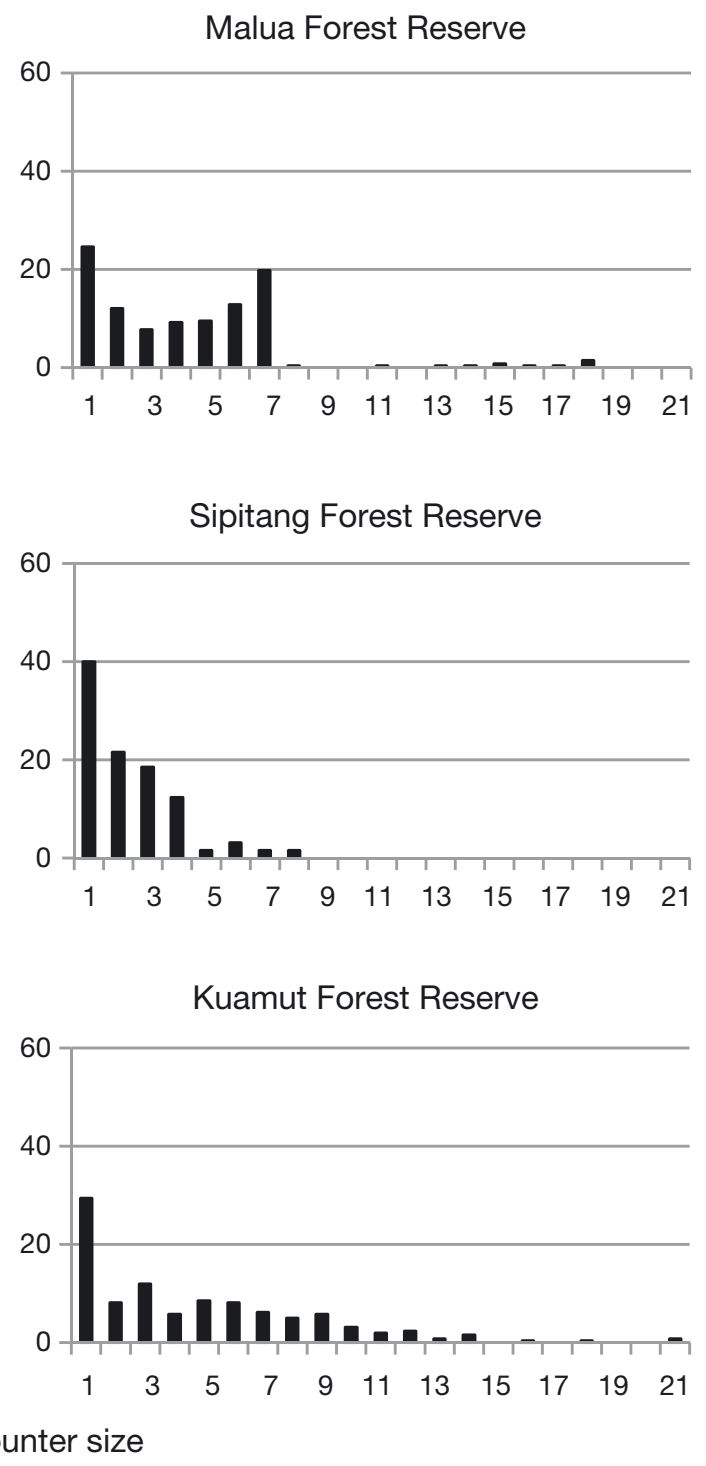

Fig. 2. Bornean banteng encounters expressed as a percentage of all events captured by camera traps within each forest reserve 
Table 4. Percentage encounter rates of herd composition according to each forest reserve. TWR: Tabin Wildlife Reserve, MFR: Malua Forest Reserve; MBCABZ: Maliau Basin Conservation Area Buffer Zones; SPTFR: Sipitang Forest Reserve; SPLFR: Sapulut Forest Reserve; KMTFR: Kuamut Forest Reserve

\begin{tabular}{|lrrrrrr|}
\hline & TWR & MFR & MBCABZ & SPTFR & SPLFR & KMTFR \\
\hline All male & 3 & 4 & 2 & 2 & 0 & 21 \\
All female & 0 & 3 & 5 & 24 & 0 & 4 \\
Mixed-sex & 26 & 48 & 34 & 16 & 22 & 30 \\
Mixed-sex + calf & 3 & 18 & 13 & 3 & 28 & 13 \\
Female + calf & 11 & 2 & 2 & 3 & 0 & 1 \\
Solitary male & 51 & 17 & 34 & 37 & 47 & 27 \\
Solitary female & 6 & 8 & 10 & 15 & 3 & 4 \\
\hline
\end{tabular}

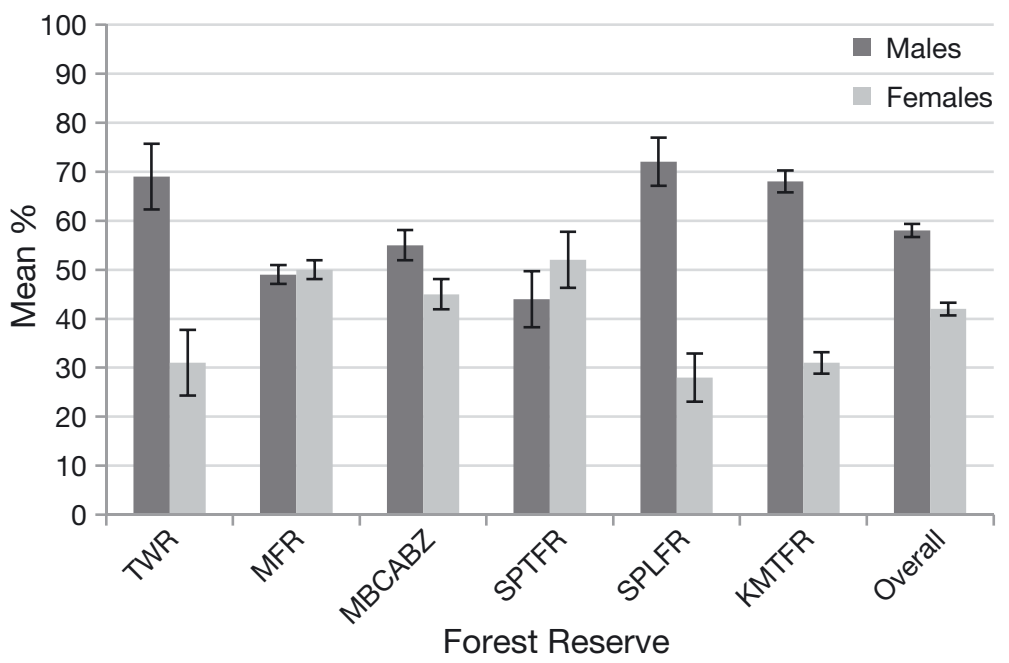

Fig. 3. Mean $( \pm \mathrm{SE})$ percentage of males and females in Bornean banteng encounters in each forest reserve. TWR: Tabin Wildlife Reserve, MFR: Malua Forest Reserve; MBCABZ: Maliau Basin Conservation Area Buffer Zones; SPTFR: Sipitang Forest Reserve; SPLFR: Sapulut Forest Reserve; KMTFR: Kuamut Forest Reserve

reserve (ANOVA: $\left.\chi^{2}=7.07, \mathrm{p}<0.05\right)$, presence of salt licks (ANOVA: $\chi^{2}=10.2, \mathrm{p}<0.01$ ), habitat vegetation (ANOVA: $\chi^{2}=30.7, \mathrm{p}<0.001$ ) and distance to the nearest forest border (ANOVA: $\chi^{2}=17.1, \mathrm{p}<0.001$ ) had significant effects upon banteng herd sizes (Table 5). Season (ANOVA: $\chi^{2}=3.08, p=0.079$ ) had a marginally non-significant effect upon banteng herd size. Explanatory terms that had no significant effect upon banteng herd sizes were removed by backwards stepwise deletion in order of the most insignificant (Table 5). The final model, which included all significant and 1 marginally non-significant explanatory terms, had normally distributed and homogenous residuals, and was deemed robust (Model 1; Table 6).
A GEEGLM of herd sizes within each forest explained by post-logging regeneration age indicated significant negative relationships, whereby herd sizes were smaller in forests with <3 yr PLR (SPTFR: OR $\pm \mathrm{SE}=$ $0.31 \pm 1.30, \mathrm{p}<0.001), 4$ yr of PLR (MFR: $\mathrm{OR}=0.68 \pm 1.09, \mathrm{p}<0.001)$ and $16 \mathrm{yr}$ of PLR (MBCABZ: OR $=0.65 \pm 1.12, p<0.001$ ) when compared to $<8 \mathrm{yr}$ of PLR (KMTFR: $\mathrm{OR}=2.01 \pm 1.19$ ), the intercept (Model 1 ; Table 6). Although herd sizes in forests with 22 yr of PLR (TWR: OR $=0.83 \pm 1.15$, $\mathrm{p}=0.1752$ ) were smaller than those with $<8 \mathrm{yr}$ of PLR (Model 1; Table 6), they did not significantly differ.

Inter-forest comparisons of herd sizes and forest sites revealed that herds on logging roads were significantly larger $(\mathrm{OR}=$ $1.30 \pm 1.10, \mathrm{p}<0.01$, Model 1; Table 6) than herds in open sites, whilst herd sizes on forest trails $(\mathrm{OR}=1.17 \pm 1.10, \mathrm{p}=0.1055)$ were not significantly different (Model 1; Table 6). Herd sizes at sites with salt licks present were significantly larger $(\mathrm{OR}=$ $1.73 \pm 1.19, \mathrm{p}<0.01)$ than herds at sites with no salt licks present (Model 1; Table 6).

Habitat vegetation had a significant effect on herd size, whereby herd sizes were larger in upland dipterocarp $(\mathrm{OR}=$ $2.56 \pm 1.34, \mathrm{p}<0.01$ ) habitats when compared to lowland dipterocarp $(\mathrm{OR}=2.01 \pm$ 1.19), the intercept (Model 1; Table 6). Distance to the forest border had a significantly negative effect on banteng herd size, with herd sizes significantly smaller closer to the forest border $(\mathrm{OR}=1.00 \pm$ 1.00, p $<0.001$; Fig. 4).

\section{Sexual segregation}

We observed a significant effect of banteng sex on capture frequencies when all captures from all forests were pooled (1-way ANOVA: $F_{2,17}=6.20$, $\mathrm{p}<0.05$, Model 2; Table 7). We found that female herds occurred significantly less frequently than male herds (Tukey post hoc test: $p<0.05$ ) and mixed-sex herds (Tukey post hoc test: $\mathrm{p}<0.05$ ). There was no significant difference between capture frequencies of male herds and mixed-sex herds (Tukey post hoc test: $p=0.983$ ). Male and mixed-sex herds contributed to 40.9 and $42.3 \%$ of 
Table 5. Backwards stepwise deletion of explanatory terms from generalised estimating equations fitted using a generalised linear model (GEEGLM) explaining Bornean banteng herd size (Model 1). The final, most robust GEEGLM model with only significant (and marginally non-significant) explanatory terms included forest regeneration age (years of post-logging regeneration), site (camera trap location), salt lick presence, sex (herd sex), habitat vegetation, distance_forest (distance to the nearest forest border) and season. Explanatory terms were removed in the order of most insignificant: canopy cover, rainfall, temperature, poaching, stolen camera stations, study design, distance_village (distance to the nearest village) and elevation. Significance denoted as: (.) $\mathrm{p}<0.1 ;{ }^{*} \mathrm{p}<0.05 ;{ }^{* *} \mathrm{p}<0.01 ;{ }^{* * *} \mathrm{p}<0.001$

\begin{tabular}{|llcccc|}
\hline $\begin{array}{l}\text { Response } \\
\text { term }\end{array}$ & Explanatory terms & $\chi^{2}$ & df & p-value & $\begin{array}{c}\text { Signifi- } \\
\text { cance }\end{array}$ \\
\hline Herd size & Regeneration age & 34.2 & 5,829 & $2.2 \times 10^{-6}$ & ${ }^{* * *}$ \\
& Site & 7.07 & 2,829 & 0.029 & $*$ \\
& Salt lick & 10.2 & 1,829 & 0.0014 & ${ }^{* *}$ \\
& Sex & 447 & 3,829 & $<2 \times 10^{-16}$ & ${ }^{* * *}$ \\
& Habitat vegetation & 30.7 & 5,829 & $1.1 \times 10^{-5}$ & ${ }^{* * *}$ \\
& Distance_forest & 17.1 & 1,829 & $3.6 \times 10^{-5}$ & $* * *$ \\
Season & 3.08 & 1,829 & 0.079 &. \\
& Elevation & 1.12 & 1,829 & 0.29 & \\
& Distance_village & 1.28 & 1,829 & 0.26 & \\
Study design & 1.07 & 1,829 & 0.3 & \\
Stolen camera stations & 0.923 & 1,829 & 0.34 & \\
Poaching & 0.289 & 1,829 & 0.59 & \\
Temperature & 0.413 & 1,829 & 0.52 & \\
Rainfall & 0.11 & 1,829 & 0.74 & \\
& Canopy cover & 0.0861 & 1,829 & 0.77 & \\
\hline
\end{tabular}

the camera trap events respectively, whilst females contributed only $16.8 \%$ of the events.

Survey durations were longer in TWR, MFR and MBCABZ and encompassed both wet and dry seasons, therefore only data from these forests was used to explore the effect of season on sex. Season had a significant effect on the capture frequency of female herds (1-way ANOVA: $F_{1,5}=19.89, \mathrm{p}<0.05$, Model 3; Table 7), with more captures obtained in the dry season $(72 \%)$ compared to the wet season $(28 \%)$; however, the seasonal effect was only marginal for male and mixed-sex herds (Models 4 and 5; Table 7).

We found a significant effect of sex upon herd size $\left(\chi^{2}=447, \mathrm{p}<0.001\right.$, Model 1; Table 5). A GEEGLM revealed that female herds $(\mathrm{OR}=2.01 \pm 1.19)$ were significantly larger than male herds (OR $=0.54 \pm 1.12, \mathrm{p}<0.001$ ), however were significantly smaller than mixed-sex herds $(\mathrm{OR}=2.35 \pm 1.09, \mathrm{p}<0.001$, Model 1; Table 6).

Table 6. Final, most robust generalised estimating equations fitted using a generalised linear model (GEEGLM) (Model 1) including the different factors of the terms regeneration age (years of post-logging regeneration [PLR]), site (camera trap location), salt lick presence, sex (herd sex), habitat vegetation, distance_forest (distance to the nearest forest border) and season. GEEGLM model estimates were converted to odds ratio, which is a measure of association between an environment and an outcome. Intercept included < 8 yr PLR (Kuamut Forest Reserve), open site, absent salt lick, female herd sex, lowland dipterocarp forest and dry season. SPTFR: Sipitang Forest Reserve; MFR: Malua Forest Reserve; MBCABZ: Maliau Basin Conservation Area Buffer Zones; TWR: Tabin Wildlife Reserve. Significance denoted by: (.) $\mathrm{p}<0.1 ;{ }^{*} \mathrm{p}<0.05{ }^{* *} \mathrm{p}<0.01{ }^{* * *} \mathrm{p}<0.001$

\begin{tabular}{|c|c|c|c|c|c|c|c|}
\hline $\begin{array}{l}\text { Response } \\
\text { term }\end{array}$ & $\begin{array}{l}\text { Explanatory } \\
\text { term }\end{array}$ & Factor & $\begin{array}{l}\text { GEEGLM } \\
\text { coefficient }\end{array}$ & $\begin{array}{l}\text { Odds ratio } \\
\text { estimate }\end{array}$ & $\begin{array}{l}\text { Odds ratio } \\
\text { standard error }\end{array}$ & $\mathrm{p}$-value & $\begin{array}{l}\text { Signifi- } \\
\text { cance }\end{array}$ \\
\hline \multirow[t]{8}{*}{ Herd size } & & Intercept & 0.7000 & 2.013752707 & 1.191246217 & $6.3 \times 10^{-5}$ & $* * *$ \\
\hline & Regeneration age & $\begin{array}{l}<3 \text { yr PLR (SPTFR) } \\
4 \text { yr PLR (MFR) } \\
16 \text { yr PLR (MBCABZ) } \\
22 \text { yr PLR (TWR) }\end{array}$ & $\begin{array}{l}-1.1700 \\
-0.3840 \\
-0.4260 \\
-0.1850\end{array}$ & $\begin{array}{l}0.310366941 \\
0.681131427 \\
0.653116342 \\
0.831104284\end{array}$ & $\begin{array}{l}1.296930087 \\
1.094830985 \\
1.120752125 \\
1.145681894\end{array}$ & $\begin{array}{c}6.3 \times 10^{-6} \\
2.3 \times 10^{-5} \\
0.0002 \\
0.1752\end{array}$ & $\begin{array}{l}* * * \\
* * * \\
* * *\end{array}$ \\
\hline & Site & $\begin{array}{l}\text { Trail } \\
\text { Logging }\end{array}$ & $\begin{array}{l}0.1540 \\
0.2590\end{array}$ & $\begin{array}{l}1.166490887 \\
1.295633805\end{array}$ & $\begin{array}{l}1.099548895 \\
1.102521688\end{array}$ & $\begin{array}{l}0.1055 \\
0.0078\end{array}$ & ${ }^{* *}$ \\
\hline & Salt lick & Present & 0.5480 & 1.729789976 & 1.186490749 & 0.0014 & $* *$ \\
\hline & Sex & $\begin{array}{l}\text { Male } \\
\text { Mixed }\end{array}$ & $\begin{array}{r}-0.6230 \\
0.8580\end{array}$ & $\begin{array}{l}0.536333023 \\
2.358439095\end{array}$ & $\begin{array}{l}1.121873438 \\
1.094612041\end{array}$ & $\begin{array}{l}5.7 \times 10^{-8} \\
<2 \times 10^{-16}\end{array}$ & $\stackrel{* * *}{* * *}$ \\
\hline & Habitat vegetation & $\begin{array}{l}\text { Seasonal freshwater swamp } \\
\text { Scrub } \\
\text { Upland dipterocarp } \\
\text { Lower montane forest } \\
\text { Industrial tree plantation }\end{array}$ & $\begin{array}{r}-0.0419 \\
0.1670 \\
0.9400 \\
0.0193 \\
0.2480\end{array}$ & $\begin{array}{l}0.958965672 \\
1.181754265 \\
2.559981418 \\
1.019487449 \\
1.281459932\end{array}$ & $\begin{array}{l}1.257342039 \\
1.291752728 \\
1.335091729 \\
1.421908524 \\
1.347161788\end{array}$ & $\begin{array}{l}0.8549 \\
0.5138 \\
0.0011 \\
0.9564 \\
0.4061\end{array}$ & $* *$ \\
\hline & Distance_forest & N/A & 0.0001 & 1.000116007 & 1.000028100 & $3.6 \times 10^{-5}$ & $* * *$ \\
\hline & Season & Wet & 0.0708 & 1.073366531 & 1.041227182 & 0.0795 & . \\
\hline
\end{tabular}




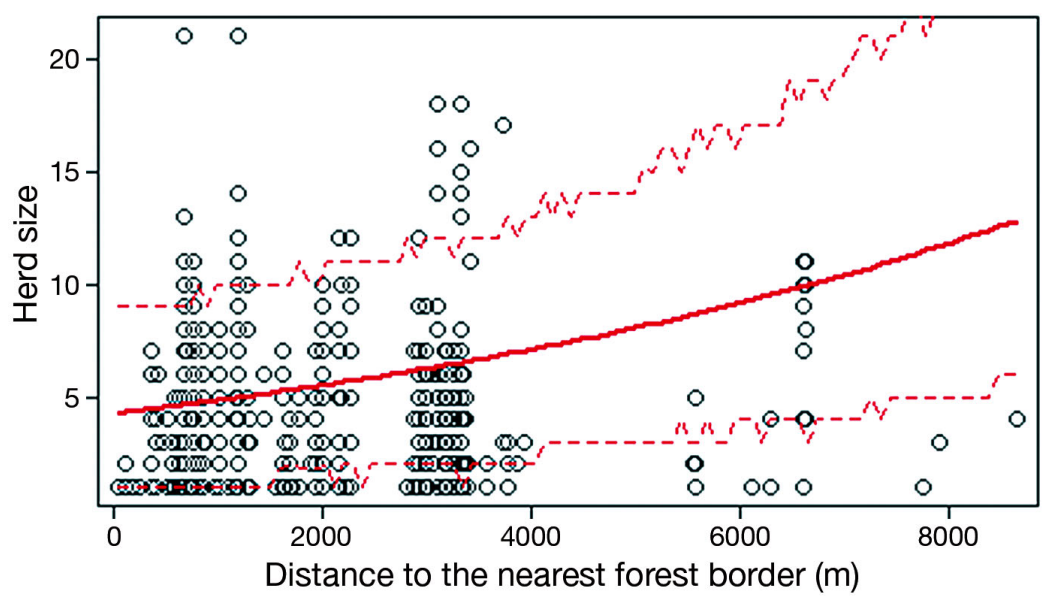

Fig. 4. Bornean banteng herd sizes at varying distances to the nearest forest border (in $\mathrm{m}$ ). Dashed lines: prediction intervals

Table 7. One-way ANOVA determining any significant differences in the capture frequency of each herd sex: male, female and mixed in all forest reserves, together with the effect of season. Significance denoted as: (.)

$$
\mathrm{p}<0.1 ;{ }^{*} \mathrm{p}<0.05
$$

\begin{tabular}{|llccccc|}
\hline $\begin{array}{l}\text { Model } \\
\text { No. }\end{array}$ & Model description & Term & F-value & df & p-value & $\begin{array}{c}\text { Signifi- } \\
\text { cance }\end{array}$ \\
\hline 2 & Capture frequency & Sex & 6.2 & 2,17 & 0.0109 & $*$ \\
3 & Female banteng & Season & 19.89 & 1,5 & 0.0112 & $*$ \\
4 & Male banteng & Season & 5.24 & 1,5 & 0.084 & $\cdot$ \\
5 & Mixed-sex & Season & 6.51 & 1,5 & 0.0632 & $\cdot$ \\
\hline
\end{tabular}

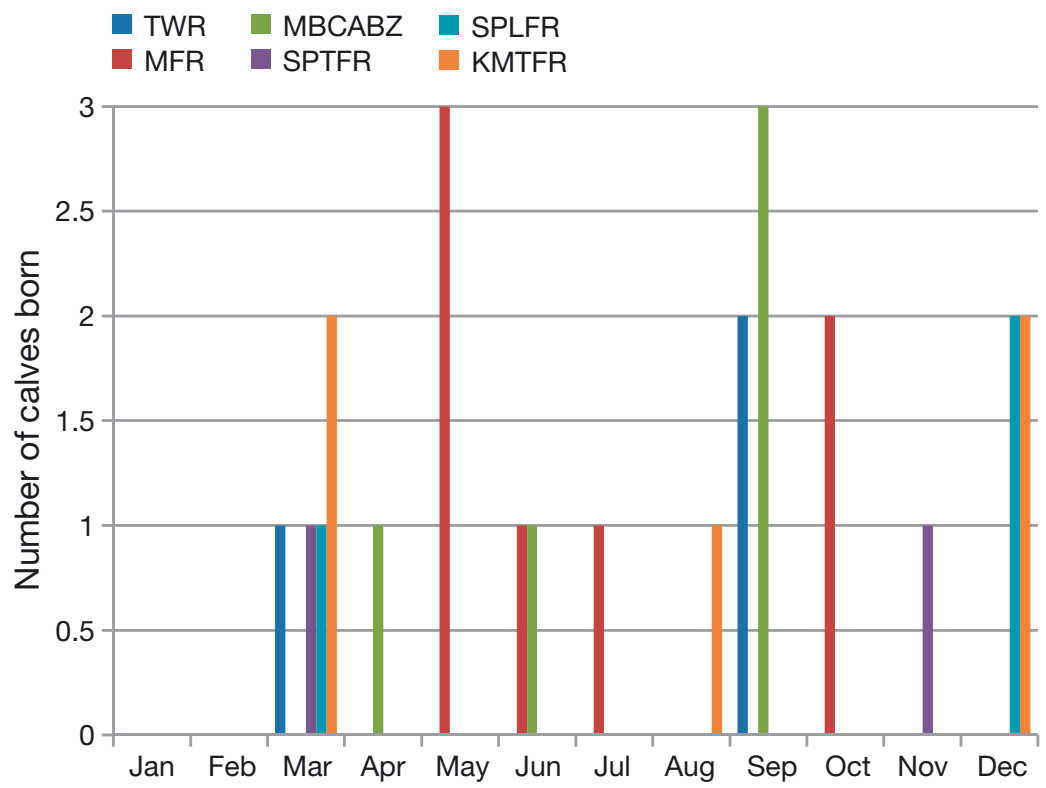

Fig. 5. Frequency of Bornean banteng calves born over the survey period in each forest reserve according to the month of the first capture of each identified calf and cow and calf approximate body size. TWR: Tabin Wildlife Reserve; MFR: Malua Forest Reserve; MBCABZ: Maliau Basin Conservation Area Buffer Zones; SPTFR: Sipitang Forest Reserve; SPLFR: Sapulut Forest Reserve and KMTFR: Kuamut Forest Reserve

\section{Calf births}

A Poisson GLM revealed that the number of calves born during the survey period did not significantly differ between the dry and wet season (Poisson GLM: LRT $=2.28$, p = 0.1308, Model 6). However, a Poisson GAM with a cyclic cubic smoothing spline revealed a significant non-linear trend of number of calves captured across months (Poisson GAM: edf $=4.23, \chi^{2}=$ 15.84, $\mathrm{p}<0.01$, Model 7). According to the month of first capture of each identified calf, births were most frequent in March and September (Fig. 5), and calf captures peaked in June and July (Fig. 6).

\section{DISCUSSION}

A total of 183 bantengs, including 25 calves, were identified in 6 forest reserves, in herd sizes ranging up to 21 individuals. Forest regeneration age, type of site, presence of salt licks, sex, habitat vegetation and distance to the nearest forest border all had significant effects on banteng herd size. A significant effect of banteng sex was found on capture frequencies. The frequency of calf births was highest in March and September, and calf captures peaked in June and July.

\section{Herd demography}

The fact that only 183 bantengs were identified in our 6 forest reserves is strong evidence of the Bornean banteng's current vulnerability. The banteng encounter range of 1 to 21 individuals differs from the 5 to 40 banteng estimated from villagers' perceptions in Sabah in 1982 (Davies \& Payne 1982). At the time of the 1982 survey, the estimation of 40 bantengs was thought to be an underestimate (Davies \& Payne 1982), suggesting a decline in herd size over time. The forest reserves containing the highest 
number of identified banteng had a larger herd size range and average, therefore, a declining population likely causes smaller herd sizes, as observed in a population of Bos javanicus birmanicus in Vietnam (Nguyen 2009). Low population densities and restrictions to home range are causing reductions, and subsequently extinctions, in other banteng populations (Pedrono et al. 2009). This is likely occurring with the Bornean banteng. Movements identified between MFR and KMTFR, which supported the largest herds, suggest that substantial and continuous forest patches are important and required for larger herds to form. Consequently, habitat reduction and fragmentation threatens the banteng population and reduces herd sizes.

SPTFR had a small number of bulls identified (10 individuals) but the highest number of bulls consistently travelling alone ( 6 individuals). KMTFR had the highest number of bulls identified (21 individuals), and was the only forest reserve to have a bachelor herd and to contain no solitary bulls. Here, the bachelor herd was dynamic in composition, with individuals regularly leaving and new bulls joining. The reduced number of males in SPTFR possibly affects bull behaviour and results in solitary lifestyles. Moreover, the number of herds repeatedly observed in SPTFR was high, therefore the choice or chance of interacting with a herd was higher than in many of the other forest reserves. Despite this, bulls

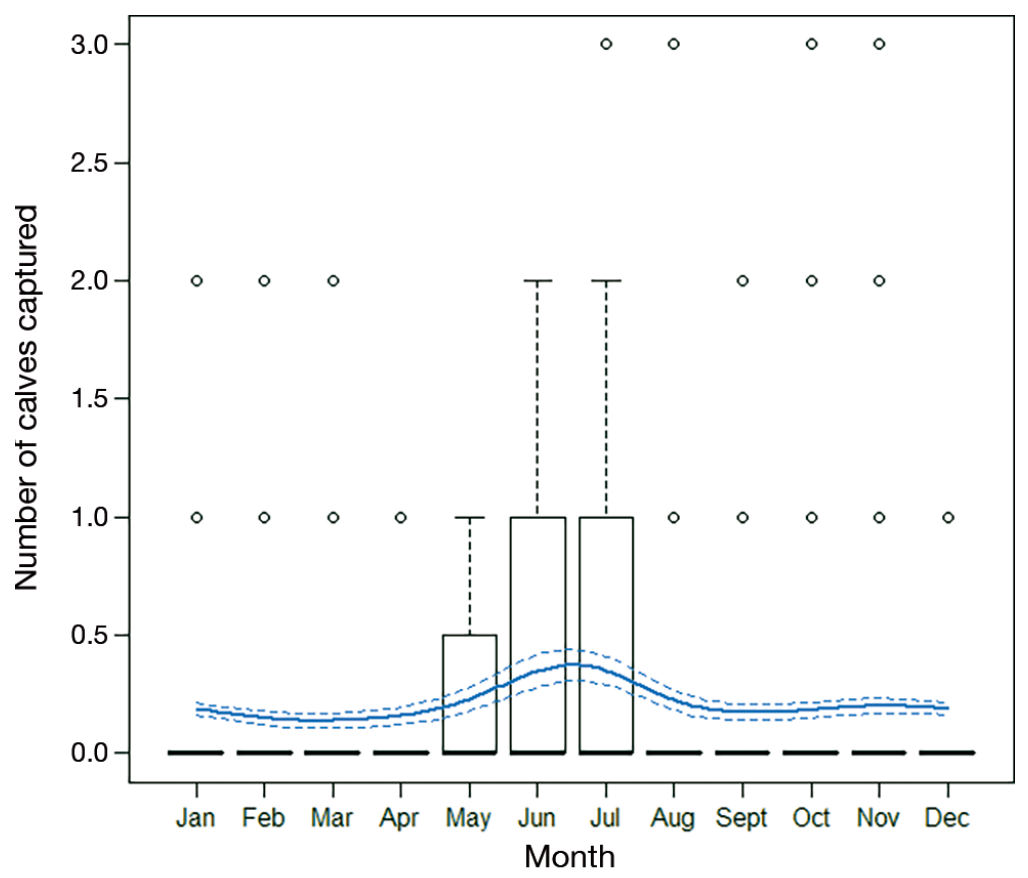

Fig. 6. Average number of Bornean banteng calves captured over the survey period in each forest reserve. Dashed lines: SE in SPTFR remained solitary. KMTFR had fewer herds but they were larger, and this may have made locating and acceptance into the herd more likely.

The bachelor herd in KMTFR was observed in 26 different combinations involving 15 mature bulls, which suggest they are very tolerant and highly social; however, the maximum herd size encountered was comprised of only 7 individuals. Additionally, due to the evidence of illegal activity encountered when surveying KMTFR, hunting and human disturbance may have caused males to form bachelor herds in order to increase vigilance and therefore survival, a behaviour that has been observed in other threatened ungulates (Averbeck et al. 2010). This dynamic bachelor herd may be an easier target for hunters; therefore, considering the evidence of illegal activity encountered during this survey, this is a major concern.

\section{Banteng herd sizes}

This study revealed that banteng herd size was significantly affected by the years of PLR. Forest in the onset stages of regeneration had the smallest herd size range, suggesting that regular use of heavy machinery and human disturbance may have weakened the bonds of association between individuals within herds. This may have resulted in smaller herds that are less permanent and prone to splitting more frequently (Pudyatmoko \& Djuwantoko 2006). Logging increases the abundance of pioneer species (Imai et al. 2012), including grasses, vines and shrubs favourable to banteng (S. Ridge unpubl. data), and regenerating vegetation benefits banteng body condition and breeding (Gardner et al. 2014, Prosser et al. 2016), which is likely to have influenced the larger herds observed in forest with $<8$ yr of PLR. Reduced disturbance from heavy machinery in the years following logging activity may have helped herds re-form and allowed herds to aggregate more frequently. MFR and KMTFR are adjacent, and banteng movement between these forest reserves was identified, showing that banteng individuals have had access to 2 forests and therefore a larger range of PLR. This would have provided increased optimal conditions to allow larger herds to form. Forest with $22 \mathrm{yr}$ of PLR would have 
increased closed areas that reduce ambient temperatures and thermal stress (P. C. Gardner et al. unpubl. data), and reduce conflict between dominant individuals and their vulnerability to poaching. This likely contributed to the larger banteng herds observed in forest with 22 yr of PLR. However, the overall effects of deforestation, heavy machinery and human presence may have raised banteng stress levels enough to negatively affect breeding, and possibly result in increased mortality (Gardner et al. 2014).

Herd sizes not significantly differing between open sites and dense forest contrasts with $B . j$. javanicus in Baluran National Park (Pudyatmoko \& Djuwantoko 2006). Gerard \& Loisel (1995) stated that large herbivores, including roe deer Capreolus capreolus and Alaskan moose Alces alces, generally have larger herds in open habitats with less canopy cover, when there is minimal disturbance. Our results, therefore, suggest that Bornean banteng are not analogous to the majority of large herbivores or even to other banteng subspecies. Bornean banteng have been observed to forage in open grasslands and socialise in open spaces (Gardner et al. 2014); however, disturbance is likely altering this behaviour and reducing herd size. Larger banteng herd sizes in upland compared to lowland dipterocarp forest suggests banteng are being forced to higher habitats for space and forage, likely a result of habitat destruction, fragmentation and human disturbance.

Larger herds on logging roads than in open sites suggest that the former provide sufficient space for larger aggregations and the opportunity to travel as a larger unit. Internal abandoned logging roads also provide banteng forage due to the increased regeneration of pioneer species over time (Gardner 2015). Moreover, logging roads provide easy access to the previously cultivated areas that provide secondary growth which banteng benefit from (Pedrono et al. 2009). Thus, more individuals will be attracted to the available forage, causing larger herds to be vulnerable to human conflict on logging roads.

Larger herds were observed in sites with salt licks than when no salt licks were present. This suggests that banteng may well be deficient in sodium and need this additional source; this is supported by a small-scaled diet-supplementation survey in Sabah that captured banteng at sites with mineral blocks and loose salt (G. H. Phillips unpubl. data), together with Davies \& Payne (1982) and Matsubayashi et al. (2007) who state that banteng require and frequently visit salt licks. It may be advantageous to implement salt licks for monitoring herds; however, doing so may make them more vulnerable to poaching.
Smaller herd sizes occurring closer to the forest border suggests they are influenced by human disturbance in the vicinity and that forest reserves must be substantial enough for banteng to express their natural demography. In contrast to the findings of Nguyen (2009), season did not have a significant influence on banteng herd size. This may imply that sufficient water sources were available in the study sites for the banteng to not aggregate, or that the conditions in the wet and dry seasons were not distinct enough to have an effect.

Although the incidences of poaching and stolen camera traps did not have a significant influence on banteng herd size, illegal activity occurred in all forest reserves (P. C. Gardner et al. unpubl. data), which likely affects their stress levels and therefore possibly breeding success, in addition to increasing their vulnerability.

\section{Sexual segregation}

Bachelor herds were observed as frequently as mixed-sex herds, therefore bulls segregated from cows, and thus this study provides evidence to support the theory of sexual segregation and is a required behaviour of bentang. Although one or several of the proposed factors (ecological, physiological, social or foraging) may cause males to segregate, they may not affect females as strongly (or at all), since female herds occurred significantly less often than bachelor herds. In addition, it is possible that females forced the bulls to leave mixed-sex herds, either due to differences in the previously stated factors, or because of birthing. Female herds being significantly larger than male herds implies that females remain in herds, and that males are possibly forced out. This is possible as Bornean cows and calves have been observed to assert authority, and younger bulls have been observed to force older bulls from herds in Java and Burma (Gardner et al. 2014).

Female herds were observed significantly more often during the dry than the wet seasons, indicating that a possible calving period is more likely to occur during the dry season. Female ungulates are more likely to segregate from males during the birth period because of behavioural and nutritional differences, and more specifically to locate suitable birthing places and to give birth (Bon \& Campan 1996 Ruckstuhl 2007). Evidence of a female banteng actively segregating itself in preparation for the birthing period was observed (see Fig. A1 in the Appendix). In contrast, no significant difference in 
the observation of male herds between seasons suggests that males do not experience the same pressures as females for niche habitat or nutritional requirements, and that they do not have a need to segregate from females during gestation.

\section{Calf births}

No evidence was found to suggest that births were elevated in either the wet or the dry season, which indicates that females experience gestation through both seasons. It is possible that both seasons provided optimal environmental conditions for breeding and therefore season was not a constraining factor. More calves born in March and September and peaks in calf captures in June and July suggests a possible calving season. More calf captures in the months following March was due to calves taking approximately 2.5 to 3 months to be categorised as juvenile. This increase in calf capture would be expected after September; however, 2 calves born in September in TWR were born at the end of camera trapping in this forest. Increased calf births in March and captures through to June is supported by the calving season of $B . j$. javanicus between April and June in Baluran National Park (Pudyatmoko \& Djuwantoko 2006). The very presence of calves indicates the potential for a population expansion; however, this area of Bornean banteng ecology requires further research.

\section{Methodology limitations}

Camera traps are a useful tool for wildlife behavioural studies, and are increasingly being used to improve species conservation (Caravaggi et al. 2017). It is, however, important to acknowledge their limitations. Dark photographs and vegetation obstruction made banteng identification impossible for some encounters. Camera trap placement has major influences on group size estimates. This study's camera trap height and location were specifically chosen to capture banteng. It was acknowledged that trails and logging roads had dense vegetation surrounding camera trap stations, making banteng more likely to travel between the 2 cameras in order to remain within the herd. It is, however, important to state that banteng are not inhibited by thick thorny vegetation, and can penetrate dense vegetation either side of trails and logging roads. When undisturbed, banteng show tendencies to follow their own trails, which was factored into the camera trap sensor area when positioning cameras. Open sites had far less vegetation to obstruct view, and when temperature decreased in open sites the range of the camera sensor had a tendency to extend. Despite the limitations of camera trapping, this survey method has been identified as superior when compared to the use of signs for detecting banteng (Gardner 2015). Camera trapping has provided conservation-relevant behavioural data of the Bornean banteng, and will act as baseline for future ecological studies aiming to assess the Bornean banteng demography.

\section{CONCLUSION}

This study has supplemented the limited knowledge and understanding of Bornean banteng ecology. The identification of banteng subpopulations and their respective herd sizes in Sabah has provided evidence of their vulnerability. This study presents baseline data of the Bornean banteng which can assist in producing appropriate management procedures that will work towards their conservation. Future land management must acknowledge the extent of habitat reduction and fragmentation, and thus ensure substantial and continuous forest patches to allow large banteng herds to form, particularly away from forest borders, and to reduce their disturbance and stress levels. Forest management should consider the stages of PLR and habitat vegetation in each forest reserve, ensuring the availability of $<8$ and $22+\mathrm{yr}$ of PLR, and suitable lowland and upland dipterocarp forest respectively, to maximise herd sizes. Banteng have adapted to habitat modifications by utilising logging roads; therefore, forest management should include restricted human access and constant monitoring. Bachelor herds being observed as frequently as mixed-sex herds, and a significantly higher capture frequency of female herds in the dry season, showed a strong indication of sexual segregation. Future research to understand banteng sexual segregation should be conducted to enhance understanding of banteng ecology and behaviour. The number of calves born did not significantly differ between seasons; however, frequency was highest in March and September, and calf captures peaked in June and July; thus, forest disturbance should be minimal during these months. The current banteng demography should be compared to the results of future research and monitoring in these 6 forest reserves, to enhance understanding and to stimulate any necessary protection measures. Incidences of 
illegal activity, including poaching, occurred in all forest reserves, therefore anti-poaching patrols should be conducted. This enhanced scientific understanding of Bornean banteng demography can facilitate science-based wildlife and forest management strategies to allow banteng re-population and ensure their long-term existence.

Acknowledgements. The authors acknowledge Sabah Wildlife Department and Sabah Forestry Department for supporting this research, the Sabah Biodiversity Centre for providing access license to P.C.G., H.Y.L., J.G.E.W. and B.G. and the Bornean Banteng Programme's field assistants Ruslee Rahman, Rusdi Saibin, Siti Hadijah Abdul Rasyak and Azzumar Mohammad, and the Professional Training Year students Naomi Prosser, Stephanie Ridge and Molly Ellis for their hard work and dedication in the field. The authors thank Stephen Vickers for providing statistical guidance. This work was funded by Sime Darby Foundation, Malaysian Palm Oil Council, Mohamed bin Zayed Species Conservation Fund, Houston Zoo and Woodland Park Zoo.

\section{LITERATURE CITED}

Achard F, Beuchle R, Mayaux P, Stibig HJ and others (2014) Determination of tropical deforestation rates and related carbon losses from 1990 to 2010. Glob Change Biol 20: 2540-2554

Apollonio M, Belkin VV, Borkowski J, Borodin OI and others (2017) Challenges and science-based implications for modern management and conservation of European ungulate populations. Mammal Res 62:209-217

Averbeck C, Apio A, Plath M, Wronski T (2010) Hunting differentially affects mixed-sex and bachelor herds in a gregarious ungulate, the impala (Aepyceros melampus: Bovidae). Afr J Ecol 48:255-264

Bon R, Campan R (1996) Unexplained sexual segregation in polygamous ungulates: a defence of an ontogenetic approach. Behav Processes 38:131-154

Boonratana R (1997) A state-wide survey to estimate the distribution and density of the Sumatran rhinoceros, Asian elephant and banteng in Sabah, Malaysia. PhD thesis, Mahidol University, Bangkok

Butler RA, Laurance WF (2008) New strategies for conserving tropical forests. Trends Ecol Evol 23:469-472

* Caravaggi A, Banks PB, Burton AC, Finlay CMV and others (2017) A review of camera trapping for conservation behaviour research. Remote Sens Ecol Conserv 3:109-122

Copland RS (1974) Observations on banteng cattle in Sabah. Trop Anim Health Prod 6:89-94

Davies G, Payne J (1982) A faunal survey of Sabah. World Wildlife Fund Malaysia, Kuala Lumpur

Fortin D, Fortin ME, Beyer HL, Duchesne T, Courant S, Dancose K (2009) Group-size-mediated habitat selection and group fusion-fission dynamics of bison under predation risk. Ecology 90:2480-2490

Gardner PC (2015) The natural history, non-invasive sampling, activity patterns and population genetic structure of the Bornean banteng Bos javanicus lowi in Sabah. PhD dissertation, Cardiff University

Gardner PC, Pudyatmoko S, Bhumpakphan N, Yindee M, Ambu LN, Goossens B (2014) Banteng. In: Melletti M,
Burton J (eds) Ecology, evolution and behaviour of wild cattle: implications for conservation. Cambridge University Press, Cambridge, p 216-230

* Gardner PC, Hedges S, Pudyatmoko S, Gray TNE, Timmins R (2016) Bos javanicus. The IUCN Red List of Threatened Species. e.T2888A46362970. http://dx.doi.org/10.2305/ IUCN.UK.2016-2.RLTS.T2888A46362970.en (accessed 19 Aug 2017)

* Gaveau DLA, Sloan S, Molidena E, Yaen H and others (2014) Four decades of forest persistence, clearance and logging on Borneo. PLOS ONE 9:e101654

* Gentry AH (1992) Tropical forest biodiversity: distributional patterns and their conservational significance. Oikos 63: $19-28$

KGerard JF, Loisel P (1995) Spontaneous emergence of a relationship between habitat openness and mean groupsize and its possible evolutionary consequences in large herbivores. J Theor Biol 176:511-522

* Gray TNE (2012) Studying large mammals with imperfect detection: status and habitat preferences of wild cattle and large carnivores in eastern Cambodia. Biotropica 44: $531-536$

* Hansen MC, Potapov PV, Moore R, Hancher M and others (2013) High-resolution global maps of 21st-century forest cover change. Science 342:850-853

Hassanin A, Ropiquet A (2007) What is the taxonomic status of the Cambodian banteng and does it have close genetic links with the kouprey? J Zool (Lond) 271:246-252

Havmøller RG, Payne J, Ramono W, Ellis S and others (2016) Will current conservation responses save the Critically Endangered Sumatran rhinoceros Dicerorhinus sumatrensis? Oryx 50:355-359

Højsgaard S, Halekoh U, Yan J (2006) The R package geepack for generalized estimating equations. J Stat Softw 15:1-11

Imai N, Seino T, Aiba S, Takyu M, Titin J, Kitayama K (2012) Effects of selective logging on tree species diversity and composition of Bornean tropical rain forests at different spatial scales. Plant Ecol 213:1413-1424

Kie JG (1999) Optimal foraging and risk of predation: effects on behavior and social structure in ungulates. J Mammal 80:1114-1129

*Main MB, Weckerly FW, Bleich VC (1996) Sexual segregation in ungulates: new directions for research. J Mammal 77:449-461

Marino A, Baldi R (2014) Ecological correlates of group-size variation in a resource-defense ungulate, the sedentary guanaco. PLOS ONE 9:e89060

Matsubayashi H, Lagan P, Majalap N, Tangah J, Sukor JRA, Kitayama K (2007) Importance of natural licks for the mammals in Bornean inland tropical rain forests. Ecol Res 22:742-748

*Maxwell SL, Fuller RA, Brooks TM, Watson JEM (2016) Biodiversity: the ravages of guns, nets and bulldozers. Nature 536:143-145

Meijaard E, Sheil D (2008) The persistence and conservation of Borneo's mammals in lowland rain forests managed for timber: observations, overviews and opportunities. Ecol Res 23:21-34

* Myers N, Mittermeier RA, Mittermeier CG, da Fonseca GAB, Kent J (2000) Biodiversity hotspots for conservation priorities. Nature 403:853-858

New Forests Ltd (2008) Malua Forest Reserve Conservation Management Plan. www.maluabank.com/downloads/ Malua_CMP.pdf (accessed 19 Aug 2017) 
Nguyen MH (2009) The status of Vulnerable gaur Bos gaurus and Endangered banteng Bos javanicus in Ea So Nature Reserve and Yok Don and Cat Tien National Parks, Vietnam. Oryx 43:129-135

Pedrono M, Ha Minh T, Chouteau P, Vallejo F (2009) Status and distribution of the Endangered banteng Bos javanicus birmanicus in Vietnam: a conservation tragedy. Oryx 43:618-625

Phan C, Gray TNE (2010) Ecology and natural history of banteng in eastern Cambodia: evidence from camera trapping in Mondulkiri Protected Forest and Phnom Prich Wildlife Sanctuary. Cambodian J Nat Hist 2:118-126

Prosser NS, Gardner PC, Smith JA, Wern JGE, Ambu LN, Goossens B (2016) Body condition scoring of Bornean banteng in logged forests. BMC Zool 1:8

Pudyatmoko S, Djuwantoko (2006) Sex ratio, herd size and composition and sexual segregation in banteng in the Baluran National Park, Indonesia. J Biol Sci 6:370-374

R Development Core Team (2012) R: a language and environment for statistical computing. R Foundation for Statistical Computing, Vienna

Reynolds G, Payne J, Sinun W, Mosigil G, Walsh RPD (2011) Changes in forest land use and management in Sabah, Malaysian Borneo, 1990-2010, with a focus on the Danum Valley region. Philos Trans R Soc Lond B Biol Sci 366:3168-3176

Roberts G (1996) Why individual vigilance declines as group size increases. Anim Behav 51:1077-1086

Ruckstuhl KE (2007) Sexual segregation in vertebrates: proximate and ultimate causes. Integr Comp Biol 47:245-257

Sabah Forest Industries (2011) Sabah Forest Industries
Sdn. Bhd. (SFI). http://avanthagroup.com/downloads/ Sabah-Forest-Industries-Sdn-Bhd.pdf (accessed 19 Aug 2017)

* Sabah Forestry Department (2005) Conservation areas information and monitoring system. http://ww2.sabah.gov. my/htan_caims/Level\%201\%20frame\%20pgs/index_ma in_fr.htm (accessed 19 Aug 2017)

Sodhi NS, Ehrlich PR (2010) Conservation biology for all. Oxford University Press, Oxford

Sodhi NS, Koh LP, Brook BW, Ng P (2004) Southeast Asian biodiversity: an impending catastrophe. Trends Ecol Evol 19:654-660

Srikosamatara S (1993) Density and biomass of large herbivores and other mammals in a dry tropical forest, western Thailand. J Trop Ecol 9:33-43

Szumilas M (2010) Explaining odds ratios. J Can Acad Child Adolesc Psychiatry 19:227-229

* Tatin L, King SRB, Munkhtuya B, Hewison AJM, Feh C (2009) Demography of a socially natural herd of Przewalski's horses: an example of a small, closed population. J Zool (Lond) 277:134-140

* Vaughan IP, Noble DG, Ormerod SJ (2007) Combining surveys of river habitats and river birds to appraise riverine hydromorphology. Freshw Biol 52:2270-2284

*Walsh RPD (1996) Drought frequency changes in Sabah and adjacent parts of northern Borneo since the late nineteenth century and possible implications for tropical rain forest dynamics. J Trop Ecol 12:385-407

*Yasuda M (2004) Monitoring diversity and abundance of mammals with camera traps: a case study on Mount Tsukuba, central Japan. Mammal Study 29:37-46 


\section{APPENDIX.}
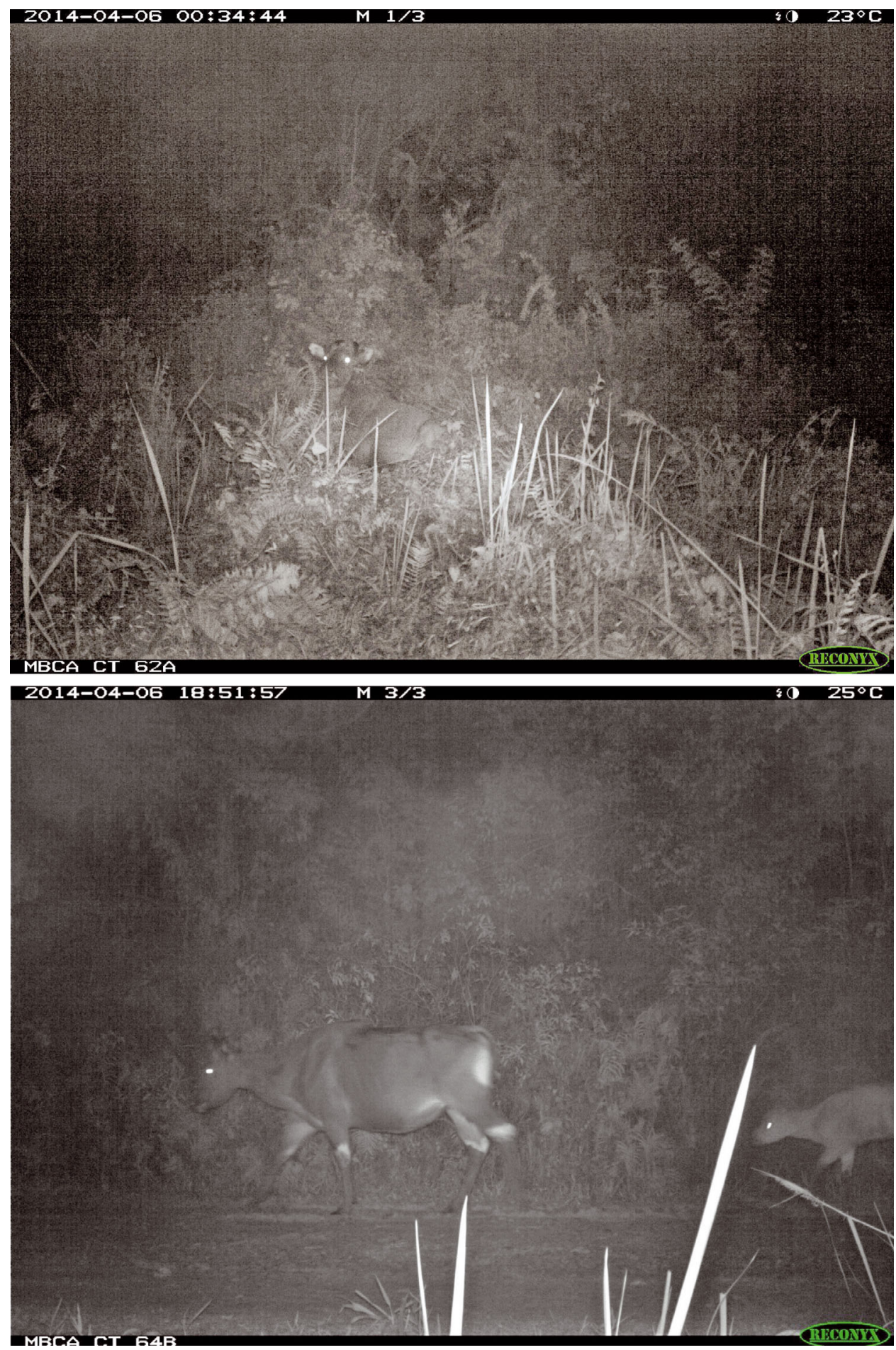

Fig. A1. Female banteng actively segregating herself in preparation for the birthing period (top image), followed by the same female banteng and her newborn calf (bottom image) on the same day (06/04/2014) in Maliau Basin Conservation Area Buffer Zones. This identified female banteng was observed regularly in a mixed-sex herd of 6 individuals before and after the birth 